\title{
Foliation of spruce in the Giant Mts. and its coherence with growth and climate over the last 100 years
}

\author{
Constantin Sander and Dieter Eckstein* \\ Institute for Wood Biology, University of Hamburg, 21031 Hamburg, Germany
}

(Received 3 January 2000; accepted 12 July 2000)

\begin{abstract}
Five spruces (Picea abies [L.] Karst.) in the Giant Mts., Czech Republic were investigated to reconstruct variations in their foliation over the last 100 years and to establish possible coherences with growth and climate. Foliation was assessed by means of the needle traces in the main trunk. The annual average needle production of 355 needles per shoot correlated with the annual shoot length and was affected by the temperature prevailing in March and October of the previous year. A determination of needle production by the length of the vegetation period is discussed. The needle retention of the trees was 6.5 needle sets on average but there were considerable long-term variations, and maximum needle age even reached 9.8 years. Needle shed was between 0.1 and 2.3 needle sets per year and no connection was revealed between needle shed and radial increment or shoot growth. Needle retention and annual needle shed were independent of climate.
\end{abstract}

Norway spruce / foliation / growth / needle traces / climate

Résumé - Les feuillages de sapins dans les Monts Kroknose et la relation entre croissance et climat au cours des 100 dernières années. Les variations du feuillage de cinq sapins (Picea abies [ L. ] Karst.) provenant des Monts Kroknose en République Tchèque, ont été étudiées sur une période couvrant les 100 dernières années afin d'établir une possible relation existant entre la croissance et le climat. Le feuillage a été évalué d'après les traces laissées par les aiguilles dans le tronc principal. La production moyenne annuelle d'aiguilles de 355 aiguilles par pousse, qui est corrélée avec la longueur annuelle de pousse, a été affectée par les températures prévalant en mars et octobre de l'année précédente. Le résultat d'une détermination de la production d'aiguille basée sur l'étendue de la période de végétation est discutée. La rétention d'aiguilles sur les arbres s'élève en moyenne à 6,5 aiguilles par pousse ancienne mais les variations à long terme sont considérables. L'âge maximum des aiguilles atteint 9,8 ans. La perte annuelle en aiguilles est comprise, par an, entre 0,1 et 2,3 aiguilles par pousse ancienne. Aucune relation n'a été établie entre la perte annuelle en aiguilles d'une part, et l'augmentation radiale ou la croissance des pousses d'autre part. La rétention et la perte annuelle en aiguilles sont ici indépendantes du climat.

épicea / feuillage / croissance / traces d'aiguille / climat

\section{INTRODUCTION}

Various bioindicators such as crown transparency and yellowing of the foliage as well as annual radial increment or annual shoot growth are used to assess a tree's vitality. Tree-ring width and shoot length are 'archived' in the tree and thus allow the construction of time series for dendroecology to reconstruct past environmental changes (e.g. [7, 9, 23]). In contrast, the foliation of a tree, due to its limited lifetime, allows only a snapshotlike assessment of its current status. Therefore the construction of long-term time series has not been feasible until recently.

* Correspondence and reprints

Tel. +40 73962 400; Fax. +40 42891 2835; e-mail: eckstein@holz.uni-hamburg.de 
However, Kurkela and Jalkanen [20] introduced a new method - the so-called needle trace method (NTM) - which allows the reconstruction of the foliation of conifers. They counted the needle traces of pine (Pinus sylvestris L.) to record past needle retention and annual needle loss and used this information, for example, in forest pathology [17]. Sander and Eckstein [25, 26] applied the same method to spruce (Picea abies [L.] Karst.) and proved that needle retention on the main stem is an adequate representation of needle retention within the entire crown of a tree.

The present study focuses on the retrospective assessment of the past foliation of spruce and its dependence on various growth parameters and climate. Although the coherence between the assimilative apparatus and biomass production of trees has already been reported earlier (e.g. [29, 31, 32]), there has so far been no investigation of how annual changes in foliation affect shoot growth and cambial activity, and no time-series approach to this question has hitherto been undertaken.

\section{MATERIALS AND METHODS}

\subsection{Materials}

Five spruce trees were chosen in a forest in the Giant Mts., Czech Republic at $800 \mathrm{~m}$ a.s.l. (table I). The site was dominated by diluvial impact but was hardly sloped. The study trees were dominant or co-dominant in a closed canopy stand, between 28 and $37 \mathrm{~m}$ tall, and ca. 120 years old. They were felled and the trunks dissected into logs of $2 \mathrm{~m}$ in length; the branches were removed. Air pollution impact was monitored for the mountainous and subalpine areas in the Giant Mts. during the 1970s and 1980s [27, 30] but it is not known whether any pollutants affected the sample site. However, there was no damage of actual foliation visible.

\subsection{Growth variables}

Each shoot length was measured between two adjacent branch whorls after cutting the shoots axially along the pith. Medial twigs - twigs between the nodii appear quite regularly and can in some cases be mixed up with whorl branches, so care must be taken when assessing shoot length. The tree-ring widths were recorded on two radii of the cross sectional area using a treering measuring table. The time series obtained were cross-dated between trees [28]. The series of the lowermost four shoots were used for calculating an arithmetic mean series per tree. Subsequently these series were aggregated into a mean tree-ring width chronology of all trees.

\subsection{Climate data}

To calculate climate-growth relationships, climate data of both monthly mean temperature and monthly precipitation sums were used (table I). Homogeneous temperature series from the stations Harrachov, Benecko and Desna Souš were provided by Brádzil (University

Table I. Sample site and climate stations in the study area.

\begin{tabular}{|c|c|c|c|c|}
\hline Location & Co-ordinates & Elevation (m) & Data-type & Data period \\
\hline $\begin{array}{l}\text { Sample site } \\
\text { Medvedi koleno }\end{array}$ & $\begin{array}{l}50^{\circ} 45^{\prime} \mathrm{N} \\
15^{\circ} 37^{\prime} \mathrm{E}\end{array}$ & 800 & Growth and foliation & 1877-1994 \\
\hline $\begin{array}{l}\text { Climate stations } \\
\text { Harrachov }\end{array}$ & $\begin{array}{l}50^{\circ} 46^{\prime} \mathrm{N} \\
15^{\circ} 26^{\prime} \mathrm{E}\end{array}$ & $680 / 708$ & Temp. + precip. & 1948-1990 \\
\hline Snezka & $\begin{array}{l}50^{\circ} 44^{\prime} \mathrm{N} \\
15^{\circ} 44^{\prime} \mathrm{E}\end{array}$ & 1602 & Precip. & 1931-1990 \\
\hline Benecko & $\begin{array}{l}50^{\circ} 40^{\prime} \mathrm{N} \\
15^{\circ} 33^{\prime} \mathrm{E}\end{array}$ & 880 & Temp. & 1946-1990 \\
\hline Desna Souš & $\begin{array}{l}50^{\circ} 46^{\prime} \mathrm{N} \\
15^{\circ} 19^{\prime} \mathrm{E}\end{array}$ & 772 & Temp. & 1930-1990 \\
\hline Jakuszyce (Poland) & $\begin{array}{l}50^{\circ} 49^{\prime} \mathrm{N} \\
15^{\circ} 21^{\prime} \mathrm{E}\end{array}$ & $871 / 910$ & Precip. & 1956-1988 \\
\hline
\end{tabular}


Brno) [2]. The precipitation series from Harrachov, Snezka and Jakuszyce (Poland) were provided by Dobry (Botanical Institute Pruhonice) and checked for homogeneity following the procedure of Holmes et al. [14]. The mean annual temperature of these stations was $4.3^{\circ} \mathrm{C}$, the mean precipitation sum was $1310 \mathrm{~mm}$. Since no single climate series supplies an adequate representation of the sample site's climate, the series were transformed by calculating regional average departures from the overall series means for each month and year [15]. Two regional climate series - one for precipitation, one for temperature - were included in the analysis.

\subsection{Revealing past needle retention}

As long as a needle is alive, it is supported by its needle trace. After the shedding of the needle, the trace will be sealed by further layers of wood. Thus, the longevity of a needle can be reconstructed retrospectively by the length of its needle trace in the wood. This mechanism can be used to reveal needle retention. The principle of needle trace assessment was first described by Kurkela and Jalkanen [20] for pine. They recorded the number of needle traces at the trunk for each shoot at its tangential surface and produced time series - analogous to tree-ring series. In spruce, however, the situation varies from pine. Whereas in pine the needle traces are represented by short shoots containing pith tissue and secondary xylem, in spruce and most other conifers of the Pinaceae family the needle traces consist of primary xylem tissue only (figure 1). Therefore the diameter of needle traces is much smaller for spruce than for pine. This anatomical difference makes the assessment with spruce more difficult and requires a modification of the method [25, 26]. Assessment of needle traces of spruce starts with the innermost tree ring close to the pith of each annual shoot. Sandblasting of the surface emphasises the varying hardness of the wooden tissue and the needle traces become visible as small "pins" (figure 2). They are arranged in diagonal lines according to the phyllotaxis of the needles. The innermost tree ring of a shoot represents the complete foliation of that shoot in the year of its formation. Subsequently the shoot is planed down tree ring by tree ring towards the bark and the needle traces are counted until finally, say after 8 or 9 years, no traces appear any more, i.e. the shoot in question is completely defoliated.

The foliation degree (DEG) of a young shoot with its complete set of needles is set as $1.0(=100 \%)$, that of a completely defoliated (older) shoot as 0 . The intermediate degrees of foliation were recorded in steps of 0.1 ( $f$ igure 3).

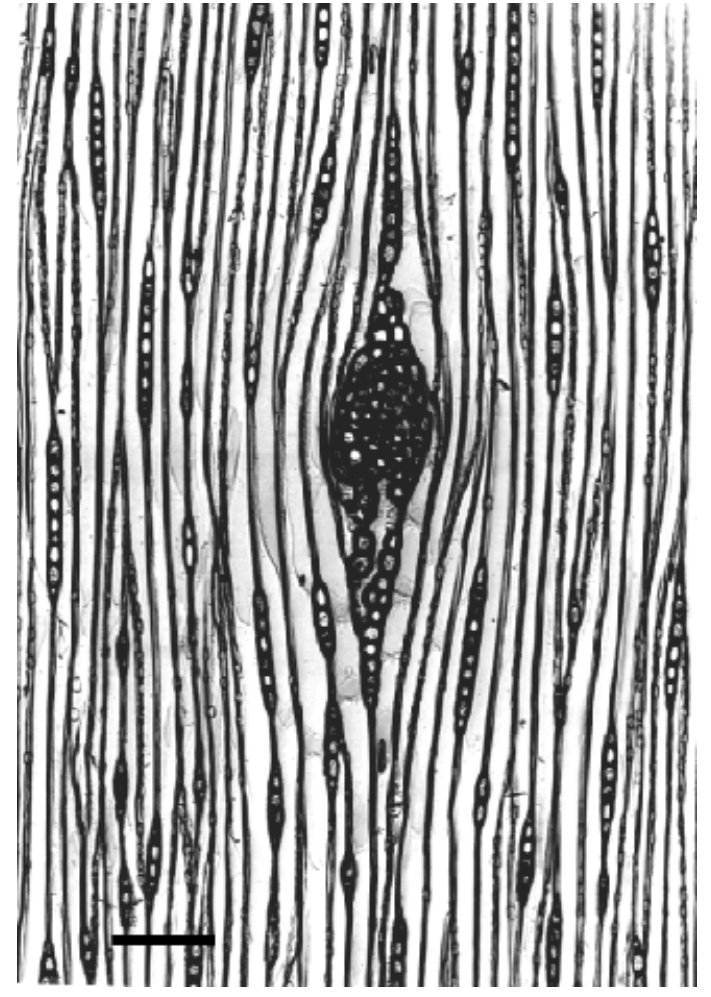

Figure 1. Needle trace of Picea abies in a thin tangential section $(20 \mu \mathrm{m})$ of the secondary xylem, bar $=200 \mu \mathrm{m}$.

DEG can be used to calculate the

- number of needle sets (SET) in year $t$, whereby $\mathrm{SET}_{t}=\sum_{a=0}^{n} \mathrm{DEG}_{t}$,

- the annual needle shed (SHED) in year $t$, whereby $\mathrm{SHED}=\sum_{a=0}^{n}\left(\mathrm{DEG}_{t-1}-\mathrm{DEG}_{t}\right)$.

In the equations $a$ characterises the annual shoots from 0 (current) to $n$ (oldest) while $t$ is the year of the tree-ring and shoot formation. SET represents the number of needle-year classes which can be found on one axis in one and the same year, SHED is the number of needle sets which were shed from the previous to the current year.

The data were aggregated for all five trees by calculating arithmetic mean chronologies. 


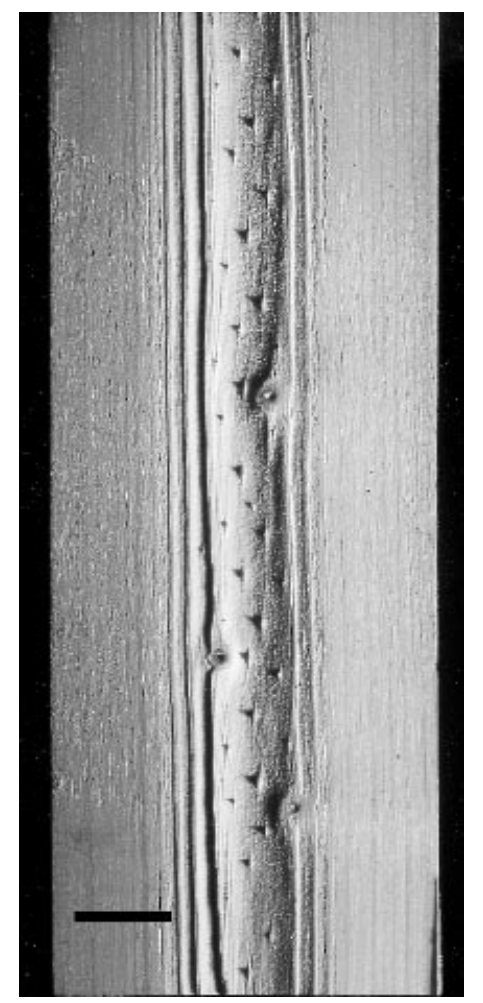

Figure 2. Needle traces of spruce after sandblasting the tangential surface, bar $=20 \mathrm{~mm}$.

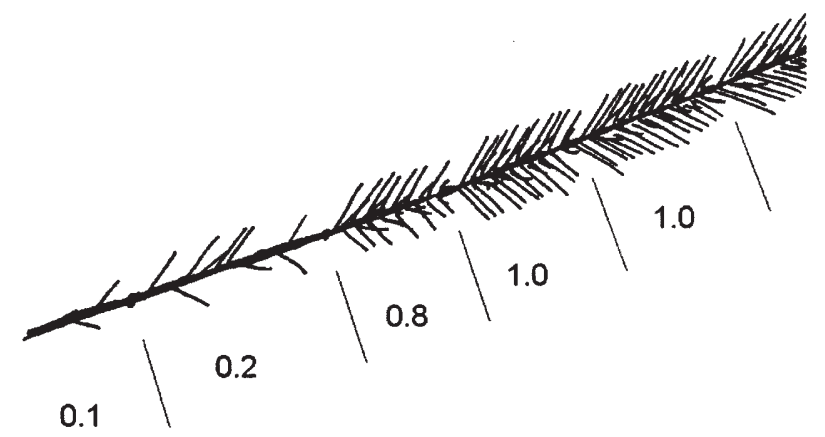

Figure 3. Needle retention on a spruce twig; numbers indicate the foliation degree of each annual shoot summing up to 4.1 needle sets in this example.

\section{CORRELATION AND RESPONSE FUNCTION ANALYSIS}

The time series of the different foliation and growth variables were compared with each other by correlation analysis. To ensure that these time series are stationary in time [6], a standardisation treatment with a cubic smoothing spline function was carried out. From the residual series mean chronologies (arithmetic mean) were established. The climatic impact on needle formation was studied using the response-function concept [9] in a slightly modified manner. The monthly mean temperature and monthly precipitation sum (independent variables) as well as the annual needle production (PROD), SET and SHED (dependent variables) entered a stepwise regression analysis as principle components. The resulting response function representing the climategrowth relationship was obtained by a bootstrap process [13] to achieve a maximum reliability of the regression.

\section{RESULTS AND DISCUSSION}

\subsection{Shoot length and radial increment}

An overview of the variation of all variables within and between trees is given in figure 4 . The annual axial increment or shoot length (SHOOT) of the five trees fluctuated between 3 and $68 \mathrm{~cm}$ (median: $30 \mathrm{~cm}$ ). Treering width (RING), calculated as a mean from the lowermost four shoots, was below $2 \mathrm{~mm}$ on average, but varied between 0.5 and $6 \mathrm{~mm}$. The mean time series of all trees reveals an age trend of RING while SHOOT is more stationary in time (figure 5).

\subsection{Needle production and needle density}

Annual needle production (PROD) of the main axis was 355 on average (median: 347), but fluctuated over time between 15 and 961 needles depending on the shoot length (figure 6). The variation between trees was 340 to 397 needles per year. Since shoot growth is controlled by the apical dominance, shoot length and number of needles is higher on the main axis than on a branch [24]. Moreover, annual needle production is controlled by genetic and/or ecological factors. The number of needles per $\mathrm{cm}$ shoot length (DENS) was 13 on average but ranged from 6 to 63 (figure 6). No long-term trends were observed. 

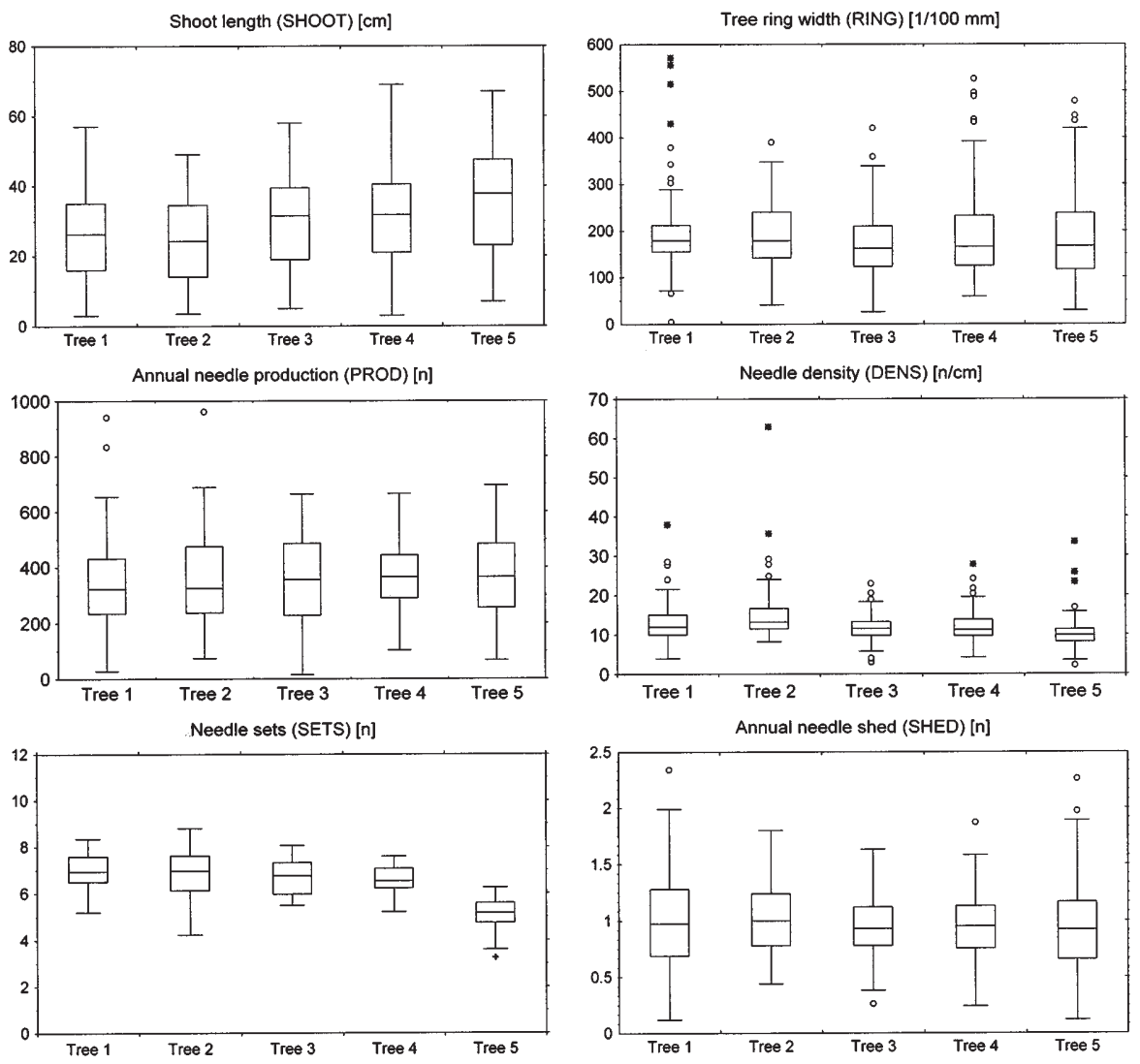

Figure 4. Variation of foliation and growth variables. Boxes represent values between the lower and the upper quartile including the median, while the whiskers show the range (min-max). Dots $\left({ }^{\circ}\right)$ and asterisks $(*)$ were used to mark outliers which are further from the median than $1.5 \times$ or $3 \times$ of the quartile range.

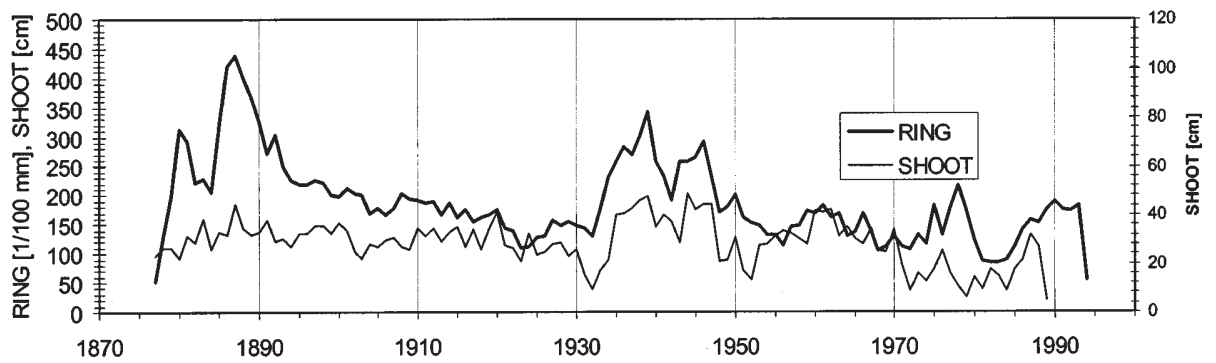

Figure 5. Shoot length (SHOOT) and mean tree ring width (RING) of five spruces on the main axis.

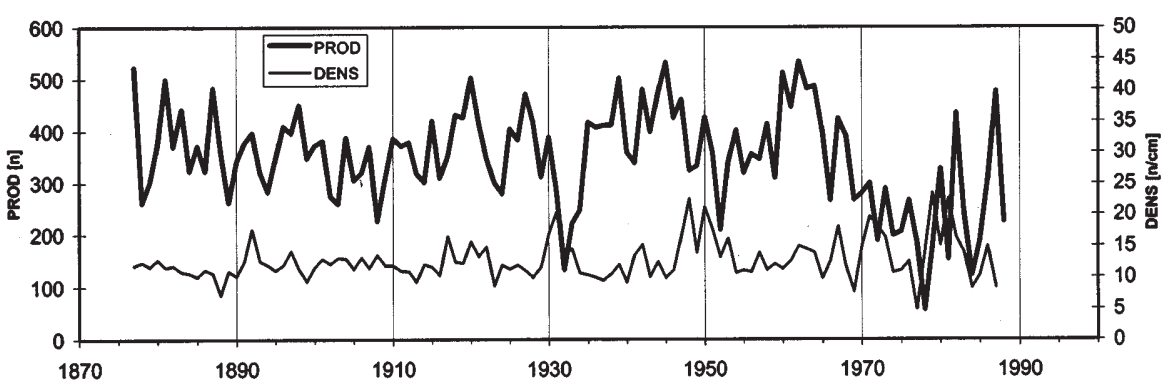

Figure 6. Annual needle production (PROD) and needle density (DENS) of five spruces on the main axis. 


\subsection{Needle retention}

The variation in needle retention in spruce and other conifers has already been reported by Burger [4] and Zederbauer [34]. Ewers and Schmid [8] proved that the variability of needle retention in pine is dependent on the altitude of the sites. The longevity of needles is positively correlated with the specific leaf area [10]. Species with long living needles have a favourable carbon balance. Thus, needle retention can be considered as an adaptation strategy to extreme growth conditions. Jalkanen and Kurkela [16] were the first to reconstruct variations in the needle retention of pine in a retrospective analysis. The present study shows that spruce, too, revealed changes in needle retention. The mean of the number of needle sets (SETS) varied between 5.1 and 7.1 between the five study trees (figure 4). The average was 6.5 years or needle sets (arithmetic mean and median). The number of needle sets reached a maximum of 8.8 , but needle age (longevity of a needle) even reached a maximum of 9.8 years. Burger [4], who studied the variation in needle retention of spruce over a vertical transect, found 6-7 needle sets to be normal at an elevation of 600-900 $\mathrm{m}$ a.s.l. The present study showed that needle retention is not constant over the lifespan of the tree, but variations were due more to long-term trends than to annual fluctuations (figure 7). The number of needle sets increased up to an age of 30 to 40 years of the spruces and decreased slightly afterwards. This phenomenon cannot be explained yet. A correlative inhibition as described by Gruber [12] is possible. Since older spruces replace their regular shoots more and more by proventive shoots, competition for water and nutrients lowers the supply of regularly formed shoots and therefore results in a lower number of needle primordia. On the other hand, long-term trends of needle retention were also found in Scots pine which does not produce proventive shoots [18]. The authors explain long-term variations with changes in growth rate and increasing stand density. In the present study, impact of air pollution cannot be taken into consideration since the slow decrease of needle retention appeared long before air pollution was reported for the Giant Mts. [30].

\subsection{Annual needle shed}

In contrast to pine, spruce sheds its needles throughout the year with a maximum in spring and autumn [12]. In the spruces investigated one needle set was shed each year on average (arithmetic mean) while the median was slightly lower due to the asymmetric distribution of the values. The actual annual needle shed of a tree (SHED) still varied from 0.1 to 2.3 needle sets but, in general, fluctuated only slightly around the mean value (figure 7). There was no indication of extreme needle loss. It must be mentioned that the death and shedding of needles do not coincide. Needle death is a physiological process while needle shedding is induced by drying and mechanical abscission of the needle [12]. However, since the needle trace is part of the needle tissue it is unlikely that it will be prolonged if the needle supported is already dead. It can thus be assumed that a needle trace really represents a living needle.

\subsection{Comparison of foliation and growth variables}

Correlation coefficients between various standardised variables are presented in a correlation matrix (table II). The close positive relationship between annual needle production and shoot length is supported by a coefficient of 0.62 and illustrated in figure 8 . Since the needle primordia are formed in the year preceding shoot elongation, shoot length is partly determined by the same factors which affect the formation of winter buds $[3,25]$. This has also been reported by Roloff [23] for oak (Quercus robur L. and Q. petraea Liebl.) and by Clements [5] for red pine (Pinus resinosa Ait.). Needle density was slightly dependent on ring width and shoot length. It is thus possible to establish some impact of growth conditions during bud break and shoot

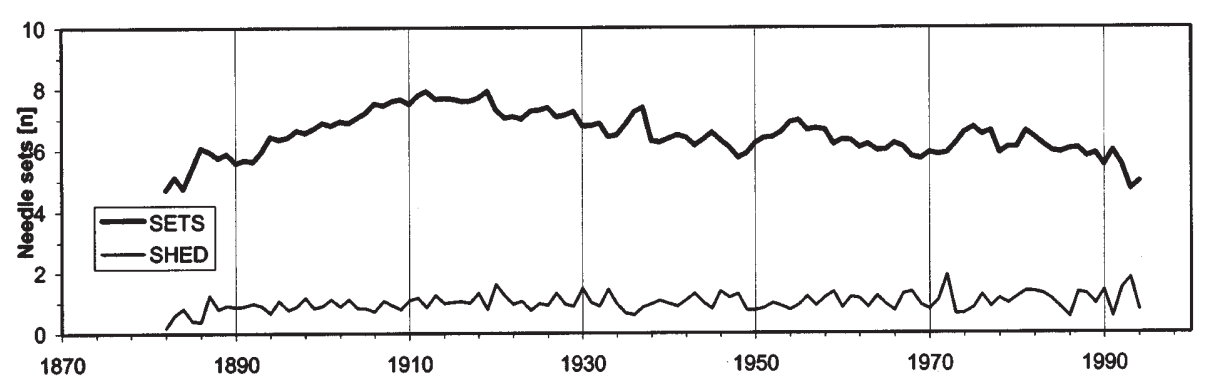

Figure 7. Number of needle sets (SETS) and mean annual needle shed (SHED) of five spruces on their main axis, from Sander and Eckstein 1997, modified. 
Table II. Correlation between foliation and growth variables (standardised). Significant values are emphasised by asterisks $(*: \alpha=0.05, * *: \alpha=0.001)$.

\begin{tabular}{lccccc}
\hline & PROD & DENS & SETS & SHED & SHOOT \\
\hline DENS & 0.26 & & & & \\
SETS & -0.06 & -0.13 & & & \\
SHED & 0.17 & -0.03 & $* *-0.78$ & & \\
SHOOT & $* * 0.62$ & $*-0.33$ & 0.20 & 0.04 & \\
RING & -0.22 & $*-0.46$ & 0.19 & -0.21 & -0.02 \\
\hline
\end{tabular}

elongation. In contrast, the radial increment at the stem base did not show any significant correlation with the contemporaneous annual needle production.

Relationships between the conductive xylem tissue and the foliation have been described in the pipe model theory by Shinozaki et al. [29]. Several further studies were able to prove a close relationship between foliation - expressed as leaf area index, leaf dry weight or leaf area, and the conductive system of a tree - expressed as sapwood area or growth rate (e.g. [19, 22]). The relationship between foliage and growth parameters is more distinct for data assessed from individual crown zones than for data aggregated for the whole crown [22]. This might also explain the low correlation of foliation parameters with the aggregated tree-ring width (within the lower trunk) in this study. If the analysis is limited to a single shoot, where the sites of assimilation and of the allocation of carbon are close together, the relationship between the annual needle production and growth becomes much stronger, too [24]. In consequence, cambial age plays a major role in this context; an older cambium "suffers" from a loss of information and of mass transfer from the assimilative apparatus.

It should be mentioned that there was no indication of forest decline from the data obtained. A slightly declining number of needle sets and radial increment can be considered a natural ageing effect probably caused by age-related declining leaf area index and primary productivity as, for example, described by Mencuccini and Grace [21].

\subsection{Response function analysis}

Foliation and growth of trees are affected by various biotic and abiotic factors. Besides genetic determination, climate and soil conditions are the most important predictors of growth processes. Recently, Aussenac [1] presented a literature review of these interactions on the forest stand level. The introduction of the time factor into such considerations makes the statistical analysis of the climate/foliation relationship feasible. This study constitutes an initial attempt to gain appropriate insight over a period of several decades.

Since winter buds are formed during the vegetation period prior to the year of shoot elongation, the period from March to October of the previous growing period was included in the step-by-step regression analysis. The temperatures in March and October - the period at the beginning and end of bud formation - had a significant impact on annual needle production ( $r=0.36, a=0.05$, figure 9). Worral and Mergen [33] report on the control of bud break by temperature. Gruber [11] describes the parallel development of the shoot and its buds and found that the final needle primordia can be initiated in October. Thus, the number of needle primordia is possibly controlled by the duration of bud formation. Low temperature in spring and/or autumn may shorten the period of primordia initiation. Neither needle retention nor needle shed revealed any coherence with climatic variables.

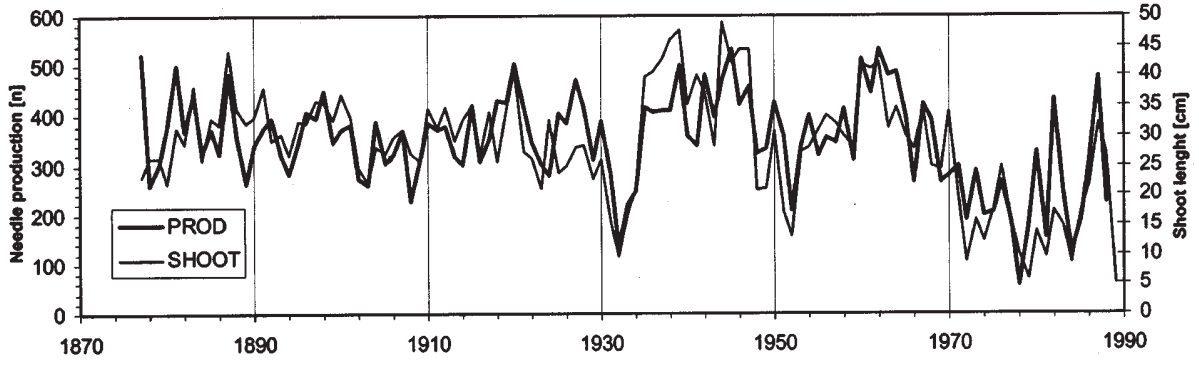

Figure 8. Coherence between annual needle production (PROD) and shoot length (SHOOT). 


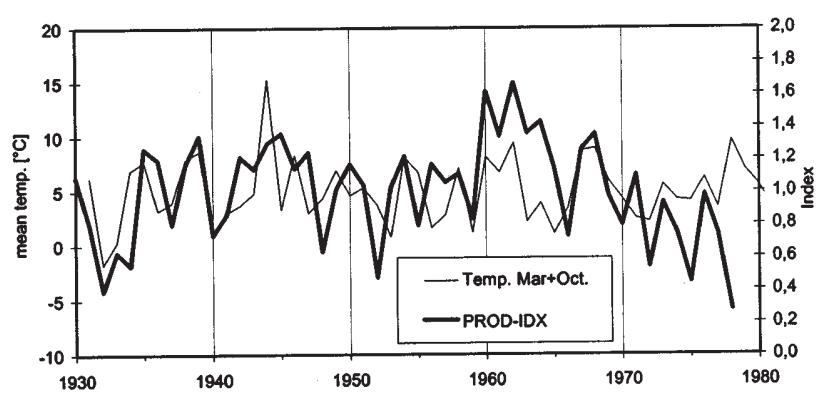

Figure 9. Relationship between March + October temperature and annual needle production (PROD).

\section{CONCLUSION}

This study was limited to the main axis of five spruce trees. One should therefore be careful about generalising the results. Nevertheless, it is possible to draw some conclusions. Needle retention is not necessarily a stationary characteristic of spruce, but can reveal long-term changes. Investigations at various ecological sites using larger sample sizes are required for a better understanding of the controlling processes. Needle retention, together with branching, affects crown transparency, hence the use of needle age or number of needle sets for forest health surveys has to take natural fluctuations of these variables into consideration. Site conditions, as well as age trends, can also affect needle retention. For the spruce trees investigated annual needle production and density along the main stem suggested a strong connection with bud formation and shoot elongation.

Acknowledgements: We would like to thank the German Science Foundation (DFG) for supporting this study and the Krkonoše National Park Service (KRNAP) for providing the sample material. The help of our student assistants Karl-Heinz Rolle, Frank Deutsch and Udo Nonnenmacher is very much appreciated. Last but not least: thanks to Yvonne Bulmer for the revision of the English text.

\section{REFERENCES}

[1] Aussenac G., Interactions between forest stands and microclimate: Ecophysiological aspects and consequences for silviculture, Ann. For. Sci. 57 (2000) 287-301.

[2] Brádzil R., Dobrý J., Kyncl J., Štephánová P., Rekonstrukce teploty vzduchu teplého pulroko v oblasi Krkonos na základe lektokruhu smrku v obdobi 1804-1989 [Reconstruction of air temperature for the summer season in the Giant Mts. based on tree-rings of spruce during the period 1804-1989], Geografie-Sbornik Ceské Geprafické Spolecnosti 102 (1997) 3-16.

[3] Burger H., Untersuchungen über das Höhenwachstum verschiedener Holzarten. [Studies on the height increment of different wood species], Mitt. Schweiz. Anst. forstl. Versuchswes. 14 (1926) 29-158.

[4] Burger H., Die Lebensdauer der Fichtennadeln. [The longevity of spruce needles], Schweiz. Zeitschr. Forstwes. 78 (1927) 372-375.

[5] Clements J.R., Shoot responses of young red pine to watering applied over two seasons, Can. J. Bot. 48 (1970) 75-80.

[6] Cook E.R., Peters K., The smoothing spline: a new approach to standardizing forest interior tree-ring-width series for dendroclimatic studies, Tree-Ring Bulletin 41 (1981) 45-53.

[7] Eckstein D., On the application of dendrochronology for the evaluation of forest damage, in: IUFRO Conf. on Inventorying and Monitoring Endangered Forests, Zürich, 1985, pp. 287-290.

[8] Ewers F.W., Schmid R., Longevity of needle fasciles of Pinus longaeva (Bristlecone pine) and other North American pines, Oecologia 51 (1981) 107-115.

[9] Fritts H.C., Tree rings and climate, Academic Press, London, New York, San Francisco, 1976.

[10] Gower S.T., Reich P., Son Y., Canopy dynamics and aboveground production of five tree species with different leaf longevities, Tree Physiol. 12 (1993) 327-345.

[11] Gruber F., Beiträge zum morphogenetischen Zyklus der Knospe, zur Phyllotaxis und zum Triebwachstum der Fichte (Picea abies [L.] Karst.) auf unterschiedlichen Standorten. [Contribution on the morphogenetic cycle of the bud, on the phyllotaxis, and on the shoot growth of spruce on different sites]. Berichte des Forschungszentrums Waldökosysteme/Waldsterben, Univ. Göttingen, Reihe A, Bd. 25, 1987.

[12] Gruber F, Verzweigungssystem, Benadelung und Nadelfall der Fichte (Picea abies). [Branching, needle foliage and needle fall of Norway spruce (Picea abies)], Birkhäuser Verl., Boston, Berlin, 1990.

[13] Guiot J., The bootstrapped response function, TreeRing Bulletin 51 (1993) 39-41.

[14] Holmes R.L., Adams R.K., Fritts H.C., Tree-ring chronologies of Western North America: California, Eastern Oregon and Northern Great Basin, Chronology Series IV, Tuscon, University of Arizona, 1987.

[15] Holmes R.L., Dendrochronology Program Library Users Manual. Laboratory of Tree-Ring Research, University of Arizona, Tucson, Arizona USA, 1994.

[16] Jalkanen R., Kurkela T., Needle retention, age, shedding and budget, and growth of Scots pine between 1865 and 1988, in: Kauppi P. et al. (Eds.), Acidification in Finland, Springer Verlag, Berlin, Heidelberg, 1990.

[17] Jalkanen R., Aalto T., Kurkela T., The use of needletrace method (NTM) in retrospectively detecting 
Lophodermella needle-cast epidemic, Eur. J. For. Path. 24 (1994) 376-385.

[18] Jalkanen R., Aalto T., Kurkela T., Development of needle retention in Scots pine (Pinus sylvestris) in 1957-1991 in northern and southern Finland, Trees 10 (1995) 125-133.

[19] Kaufmann M.R., Troendle C.A., The relationship of leaf area and foliage biomass to sapwood conducting area in four subalpine forest tree species, Forest Sci. 27 (1981) 477-482.

[20] Kurkela T. Jalkanen R., Revealing past needle retention in Pinus spp., Scand. J. For. Res. 5 (1990) 481-485.

[21] Mencuccini M, Grace J., Hydraulic conductance, light interception and needle nutrient concentration in Scots pine stand and their relations with net primary productivity, Tree Physiol. 16 (1996) 459-468.

[22] Oren R., Werk K.S., Schulze E.D., Relationships between foliage and conducting xylem in Picea abies (L.) Karst., Trees 1 (1986) 61-69.

[23] Roloff A., Entwicklung und Flexibilität der Baumkrone und ihre Bedeutung als Vitalitätsweiser. II. Kronenentwicklung und Vitalitätsbeurteilung der Eichen, Reiterationen, Kurztrieblebensdauer und Beziehungen zwischen Krone und Wurzel [Development and flexibility of the tree crown and its relevance as a vitality indicator. II. Crown development and vitality indication of oak, reiterations, short shoot longevity and relation between crown and root], Schweiz. Zeitschr. Forstwes. 140 (1989) 943-963.

[24] Sander C., Retrospektive Erfassung der Benadelung von Fichten (Picea abies [L.] Karst) mit Hilfe des Nadelspurverfahrens. [Retrospective assessment of the foliation of spruce by means of the needle trace method], Dissertation Thesis, Univ. Hamburg, 1997.

[25] Sander C., Eckstein D., Reconstruction of the foliation of Picea abies by means of needle traces, Scand. J. For. Res. 9 (1994) 311-315.
[26] Sander C., Eckstein D., Retrospektive Erfassung der Benadelung von Fichten anhand der Nadelspuren im Stamm. [Retrospective assessment of the foliation of spruce by means of needle traces in the trunk], Forst und Holz 52 (1997) 643-646.

[27] Sander C., Eckstein D., Kyncl J., Dobry J., The growth of spruce (Picea abies (L.) Karst.) in the Krkonoše-(Giant) Mts. as indicated by ring width and wood density, Ann. Sci. Forest. 52 (1995) 401-410.

[28] Schweingruber F., Der Jahrring: Standort, Methodik, Zeit und Klima in der Dendrochronologie. [The annual ring: site, methodology, time and climate in dendrochronology], Haupt Verlag, Bern, Stuttgart, 1983.

[29] Shinozaki K., Yoda K., Hozumi K., Kira T., A quantitative analysis of plant form - the pipe model theory. I + II, Jap. J. Ecol. 14 (1964) 97-105; 133-139.

[30] Vacek S., Lepš J., Changes in the horizontal structure in a spruce forest over a 9-year period of pollutant exposure in the Krkonose Mountains, Czechoslovakia, Forest Ecology and Management 22 (1987) 291-295.

[31] Valentine H.T., Gregoire T.G., Burkhart H.E., Hollinger D.Y., A stand-level model of carbon allocation and growth, calibrated for loblolly pine, Can. J. For. Res. 27 (1997) 817-830.

[32] Vanselow K., Krone und Zuwachs der Fichte in gleichaltrigen Reinbeständen. [Crown and increment of spruce in even-aged stands], Forstwiss. Centralbl. 70 (1951) 705-719.

[33] Worral J., Mergen F., Environmental and genetic control of dormancy in Picea abies, Physiol. Plant. 20 (1967) $733-745$

[34] Zederbauer E., Beiträge zur Biologie der Waldbäume. II. Lebensdauer der Blätter. [Contribution on the biology of forest trees], Centralbl. Ges. Forstw. 42 (1916) 339-341. 